\title{
Barriers to Creative Destruction: Large Firms and Nonproductive Strategies
}

\author{
Salomé Baslandze
}

\section{Working Paper 2021-23}

September 2021

\begin{abstract}
This working paper reviews recent empirical evidence on large firms and nonproductive strategies that hinder creative destruction and reallocation. The focus is on three types of nonproductive strategies: political connections, nonproductive patenting, and anticompetitive acquisitions. Across different contexts using granular micro data sets, we overwhelmingly see that as firms gain market share, they increasingly rely on nonproductive strategies but reduce their productive, innovation-based strategies. I also discuss theoretical channels, aggregate implications, and potentials for some policies.

JEL classification: 03, 04
\end{abstract}

Key words: creative destruction, innovation, growth, patents, political connections, firm dynamics https://doi.org/10.29338/wp2021-23

This working paper is based on the presentation at the festschrift symposium "Economics of Creative Destruction" in honor of Philippe Aghion and Peter Howitt. The author thanks the symposium participants for their comments. The views expressed here are those of the author and not necessarily those of the Federal Reserve Bank of Atlanta or the Federal Reserve System. Any remaining errors are the author's responsibility.

Please address questions regarding content to Salomé Baslandze, Federal Reserve Bank of Atlanta, 1000 Peachtree St. NE, Atlanta, GA 30309, salome.baslandze@atl.frb.org.

Federal Reserve Bank of Atlanta working papers, including revised versions, are available on the Atlanta Fed's website at www.frbatlanta.org. Click "Publications" and then "Working Papers." To receive e-mail notifications about new papers, use frbatlanta.org/forms/subscribe. 


\section{Introduction}

A Schumpeterian notion of creative destruction (Schumpeter, 1942), first formally introduced in growth theory by Philippe Aghion and Peter Howitt (Aghion and Howitt, 1992), opens up the possibility for conflict over technologies to affect the growth process. Different firms resolve this conflict differently. Some firms may rely on productive strategies to help them win the market, while others rely on non-productive strategies that help them protect the existing market positions without innovating.

Productive strategies, such as innovation, let firms gain a competitive advantage through new or better-quality product offerings or more efficient ways of producing existing goods. These strategies create value to society by moving the technology frontier and advancing aggregate productivity growth. Non-productive strategies, such as the firms' reliance on political connections, non-productive patenting, or anti-competitive acquisitions, are often aimed to increase a firm's competitive advantage by blocking creative destruction and reallocating resources away from other firms. The focus of this chapter is on the firms' choice between these strategies. The allocation of firms' efforts between productive and non-productive strategies ultimately determines the economy's growth and aggregate welfare (Baumol, 1990; Murphy et al., 1991).

Theoretically, it has been recognized that vested incumbents have incentives to hinder creative destruction. In the environments where firms can influence entry policies, Krusell and Rios-Rull (1996) and Mukoyama and Popov (2014) showed that incumbents make an effort to prevent the adoption of new technologies, ultimately lowering aggregate growth. In recent work, Glode and Ordoñez (2021) theoretically show that with the advancement of technologies, these rent-seeking activities actually may be even more fruitful, thus posing the possibility that rent-seeking might be on the rise.

Empirically, what are these non-productive strategies that preserve firms' market positions by lowering creative destruction? What are the characteristics of firms employing these strategies, how prevalent are they, and what are the aggregate implications?

Although anecdotal evidence and casual observations abound, detailed evidence using novel micro-level datasets, combined with insights from theory, is needed to speak to the nature and extent of non-productive strategies among firms. Identifying these strategies will help us make better policy recommendations and identify institutions amenable to strategic manipulation. This chapter reviews the recent evidence based on granular microdata that identifies various forms of firms' non-productive strategies and discusses its aggregate implications for innovation and creative destruction.

I focus on three types of non-productive strategies for which micro-level evidence 
is mounting: political connections, non-productive patenting, and anti-competitive acquisitions. Across different contexts (Akcigit et al., 2018; Argente et al., 2020), we overwhelmingly find that as firms gain market shares, they rely more on non-productive strategies but reduce their productive, innovation-based strategies.

This evidence can be easily understood through the lens of two classic effects in the economics literature: Arrow's replacement effect (Arrow, 1962) and "preserving-themarket" effect similar to Gilbert and Newbery (1982). While market leaders have lower incentives for innovations, they have higher incentives to protect larger rents through non-productive strategies. It is essential to evaluate both static and dynamic effects from non-productive strategies to understand the aggregate implications of this evi-

dence. Statically, some of these strategies may create value (e.g., through lowering certain market frictions or via static gains from reallocation). Still, dynamically, losses through lower creative destruction and innovation may be even more significant.

In addition to micro-level studies opening our eyes on empirical evidence, there is a need for quantitative structural evaluation of these findings for the macroeconomy, especially in light of recent trends on the increasing market power, slower business dynamism, and stagnating productivity growth (Decker et al., 2016; Autor et al., 2020; Gutiérrez and Philippon, 2017; De Loecker et al., 2020; Akcigit and Ates, 2021). Important works in this direction are discussed.

In the following sections, I review recent empirical evidence that, with unique microlevel datasets, is able to show the existence and prevalence of various non-productive strategies. I discuss the evidence on political connections, non-productive patenting, and anti-competitive acquisitions. After providing the micro evidence and theoretical intuition, I discuss existing quantitative macro studies that quantify related strategies and consider potential policy implications. I conclude by highlighting the areas for future research.

\section{Large Firms, Political Connections, and Creative De- struction}

\subsection{Italy}

How do political connections help firms? What are the aggregate implications of political connections for the economy? It is challenging to answer these questions jointly because of the lack of systematic data on firms' connections at a large scale. By match- 
ing multiple administrative data sources, a recent study by Akcigit et al. (2018) compiles the data set with direct measures of firm-level political connections for the whole private sector in Italy over multiple decades. The wealth of systematic microdata provides important lessons for the macro outcomes: the widespread connections of large incumbents set back incumbents' innovation efforts, create barriers to creative destruction, and, as a result, are detrimental for aggregate dynamics. I will discuss the findings of this study in more detail next.

Data, measurement, and institutional context. Directly measuring the connections between firms and politicians is a challenging task - many relationships are hard to track, exchange of favors is often not observed. The empirical literature has made considerable progress by findings ingenious ways to proxy for political connections in various contexts (see Akcigit et al. (2018) for an extensive literature review). The empirical approach we take in Akcigit et al. (2018) detects firm-level political connections using formal employment relationships between firms and local politicians in Italy. In Italy, local politicians serving at the municipal, provincial, or regional level can at the same time be employed in the private sector. By matching the universe of the employer-employee dataset from the social security records with the administrative registry of local politicians in Italy, we systematically track employment-based political connections at the firm level.

As a result, a firm is defined as politically connected at a point in time if the firm employs at least one local politician in that year. Local politicians in Italy hold various levels of legislative and executive positions: they are often the members of the local government councils but also may hold high-rank positions, such as mayors, provincial or regional presidents. Using data on politicians' party affiliation, politicians can also be categorized as majority/minority party or coalition members. Thanks to this heterogeneity in politicians' power, different levels of political connections can be defined. For example, the firm is defined as having a majority-level or high-rank connection if the firm employs a politician who belongs to the majority party or holds a high-rank position, respectively.

We match our firm-level data with firms' financial information and patent data, allowing us to evaluate multiple dimensions of firm performance. Our dataset spans the period 1985-2014 and tracks more than four million distinct firms and 500 thousand local politicians over time. We identify 449 thousand firm-year observations with political connections for 112 thousand unique firms. Across industries, on average, $5 \%$ of firms are connected, but they account for a third of employment. 
How meaningful are connections with local politicians? Political connections identified using the employment of local politicians clearly capture just a subset of many possible links between firms and bureaucrats. For example, politicians at the national level are not in our data. However, higher-level connections at the firm level would presumably leave a paper trail in the form of connections we identify. In addition, due to Italy's decentralized government system (8,110 municipalities, 103 provinces, and 20 regions), local politicians hold substantial power, and connections with local politicians may go a long way in helping firms "grease the wheels of commerce". Among other things, local politicians administer most of the bureaucratic procedures faced by firms, oversee the issuance of permits or licenses, and provide local public goods and services.

Why does Italy provide a good context to study the micro and macro aspects of political connections? In addition to the opportunity to build the wealth of microdata with direct measures of political connections, we can link the insights we learn from microdata to important macro trends of the Italian economy over the past decades. The declining productivity growth and worsened business dynamism characterize many advanced economies in the past decades; however, the Italian experience has been particularly poor. To show this, Panel (a) in Figure 1 plots the 3-year moving average growth rate of GDP per capita in Italy. Panel (b) plots the share of large firms (with more than 100 employees) connected with high-rank politicians. With a stark decline in growth rate, the economy saw a significant increase in large incumbents' reliance on political connections. Although these figures are suggestive, in Akcigit et al. (2018), we try to link these phenomena - political connections and negative aggregate dynamics - by delving into microdata analysis and guided by the theoretical insights from the economics of creative destruction and growth.

Delving into microdata. The analysis starts by exploring the firm-level data to gain insights into possible channels through which political connections affect firms and the aggregate economy. Political connections represent non-productive strategies if the firms use their connections for private gains without innovating or advancing productivity. Connections do not necessarily have to be non-productive if, for example, firms use the help of bureaucrats to bend certain regulations that hinder the entry and adoption of new products or services. A look into the firm's innovation, growth, and productivity dynamics when acquiring connections helps distinguish between political connections' productive and non-productive nature.

First off, we document reliance on innovation and political connections for firms with different market shares. We rank firms based on their employment shares in their 
Figure 1: Declining Growth and Rising Connections of Large Firms in Italy

(a) GDP per capita growth, Italy

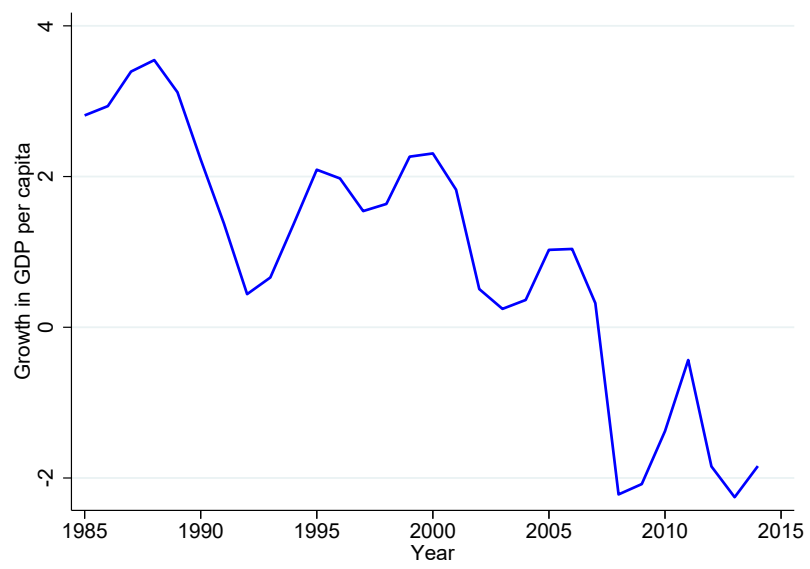

(b) Share of connected large firms, Italy

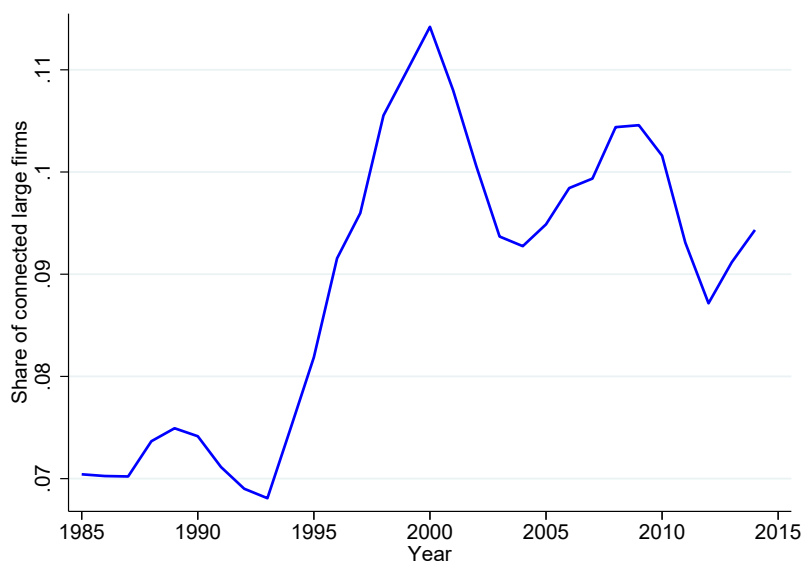

Notes: Panel (a) plots a 3-year moving average of GDP per capita growth in Italy over time. Panel (b) is taken from Akcigit et al. (2018) and plots the average share of large firms across Italian industries that are connected with high-rank politicians. A large firm is defined as a firm with more than 100 workers. The firm is connected with a high-rank politician if it employs at least one worker who at the same time serves as a mayor, region/province president, vice-mayor or vice-president, or president/vice-president of a local government council.

respective industries and regions over time. The figure 2 then plots for each rank the average innovation intensity - the number of patent applications over 100 white-collar workers, and the average connection intensity - the number of employed politicians over 100 white-collar workers, adjusted for industry, region, and year fixed effects. We see that firms with larger market shares tend to rely less on innovation but turn to political connections more intensively. These patterns hold for various proxies of firm innovations, connectedness, and definitions of market shares. If these connections were productive, we would see the opposite picture, with connections and innovation efforts going hand in hand.

Moving forward, we see more evidence for the non-productive use of political connections by market leaders. We observe that although connections lead to firm growth in size, these connections do not lead to increased productivity of firms. Using firmlevel OLS and fixed effect regressions and conditioning on other firm-level controls, the paper shows that moving from no connection to connection is associated with a 1 to 4 percentage point increase in firms' growth in employment and value added, but, if anything, a small negative growth in firm's productivity, measured by labor productivity or TFP. This growth in size is temporary, and it is larger for firms connected with majority- 
level politicians. Firm-level connections are also associated with longer survival in the market, higher profits, but not higher expenses on intangibles or expanding patenting.

Although instructive, these firm-level correlations may be driven by other factors, making it hard to make causal statements. We exploit random variation caused by local elections decided on a thin margin to move forward with causal identification. In our regression discontinuity design (RDD), we compare post-election outcomes of firms that right before the election employ individuals who become majority or minority-party politicians. Since elections are decided on a thin margin ("by chance"), the identifying assumption is that the elections randomize treatment (winning) across ex-ante identical firms. Indeed, balancing tests shown in the paper support the assumption of randomization - winning and losing firms are ex-ante similar on many dimensions. However, the post-election outcomes of these firms differ. As before, firms connected with winning politicians relative to those whose politicians turned out in minority gain by growing in size, although not in productivity.

Although RDD gives us local treatment estimates specific to the narrow contexts of marginal elections, this design presents a credible identification exercise. Combined with our earlier firm-level estimates on the entire sample of firms, these exercises tell us one story: firms rely on political connections mainly for non-productive reasons, and this is particularly prevalent among large market leaders.

Macro implications and channels. The effects of non-productive strategies exploited by existing incumbents go beyond the private gains and can have dire consequences for aggregate firm and productivity dynamics. To see this, we first turn to the theory of creative destruction to which this volume is devoted. In Akcigit et al. (2018), we develop a simple theory of innovation, creative destruction, and growth, where firms choose both innovation and political connections. To model political connections, we adopt the most "innocuous" approach and introduce wedges to the firms' cost (e.g. Restuccia and Rogerson, 2008; Hsieh and Klenow, 2009; Garicano, Lelarge and Van Reenen, 2016) to stand for market frictions that political connections could mitigate.

Our modeling choices are guided by empirical evidence. The model is consistent with the micro evidence discussed above and gives us insights into the macro implications of the micro behavior. As in standard Aghion and Howitt (1992), it is entrants who have incentives for innovation, not incumbents. However, on the contrary, large incumbents are more likely to get politically connected: for them, the gains from reducing wedges outweigh the costs of connections. These dynamics result in large firms' relying less on innovation but more on political connections. As in the data, getting connected 
Figure 2: Innovation and Political Connections Intensity over Firm's Market RANK

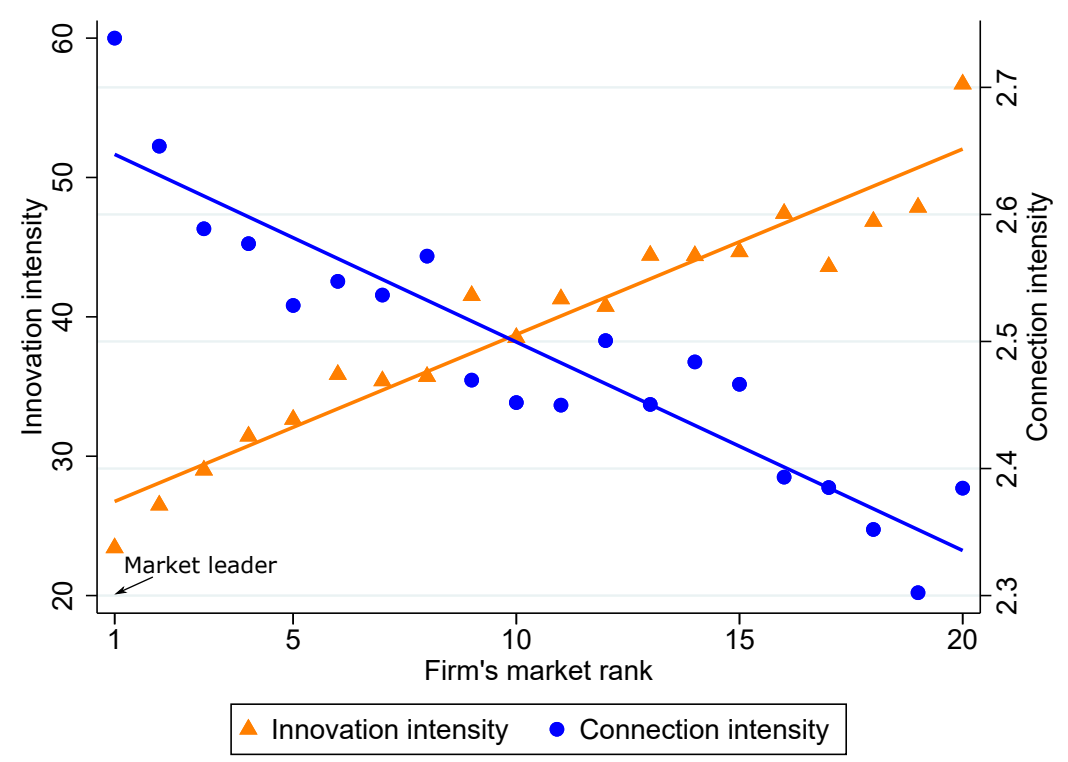

Notes: The figure is reproduced from Akcigit et al. (2018). On the x-axis, firms are ranked based on the employment share in their industry $\times$ region in a year. Hence, the market rank equal to one denotes market leaders. Orange triangles depict the average innovation intensity measured as the number of patent applications, normalized by firm size (100 white-collar workers). Blue circles denote connection intensity measured as the number of politicians employed in a firm, again normalized by firm size. Both outcome variables are adjusted for industry, region, and year fixed effects. The blue and orange lines depict regression lines from regressing connection and innovation intensities on market rank, controlling for industry, region, and year fixed effects.

is then associated with growing size due to reduced market frictions, but no positive effects on productivity.

We use the model to gain an understanding of the aggregate implications of political connections. The key is to understand how creative destruction works. In standard models, creative destruction occurs when new innovators improve on the existing incumbents' technologies. Better technologies outcompete the old ones. Not necessarily in this model. If current incumbents are politically connected and face lower wedges than non-connected entrants, this unequal distribution of wedges puts entrants at a disadvantage, effectively raising the bar for replacement through innovation. As a result, although connections are modeled "innocuous", political connections' non-productive and uneven nature leads to an aggregate decline in creative destruction, innovation, and ultimately growth. 
In the paper, we turn to macro data to verify the aggregate implications of the model. Consistent with the theory, we find that political connections are linked with worse industry dynamics across different markets. Creative destruction and reallocation are lower in markets characterized by a big share of incumbents' connections.

What do these wedges in the model represent? In Akcigit et al. (2018), we show that government regulations and bureaucracy are the most relevant channels through which political connections transmit into poor performance of the economy. We see that incumbents in industries facing the largest burden of bureaucracy and regulations are more likely to be politically connected. The connected incumbents in these industries also benefit most from employing political connections. Hence, regulations and poor bureaucracy (which deteriorated over time in Italy, Gratton et al. (2021)) are a mediating channel through which political connections affect firm dynamics and growth.

\subsection{Other contexts}

Although the empirical setting in the paper applies to Italy, there are no reasons to think the findings and intuition from the model are specific to the Italian experience. I briefly review other recent evidence about political connections in the context of creative destruction (for a review of different aspects, see Akcigit et al. (2018)).

Across countries, Comin and Hobijn (2009) show that lobbying dampens the adoption of new technologies. It is especially the case when incumbents in the adopting country are vested in old technologies, which are close predecessors to new technologies. In a related strand of works, incumbent firms are shown to lever their political connections against foreign competition. In another chapter of this book (which also provides an excellent review of related literature), the authors show the evidence of lobbying used to deter foreign competition in response to the import shock in the U.S. (Bombardini et al., 2021). This lobbying is particularly pronounced among firms behind the technology frontier, again supporting that innovation and political connections go in opposite directions.

Gutiérrez and Philippon (2019) find the declining elasticity of entry to industry's median Tobin's $Q$ over time in the U.S. That is, the firms enter less into industries where existing firms have larger market values. The authors' analysis shows that an increase in regulations and lobbying expenditures by firms in high-Q industries is likely a significant driver of this decline in the "free entry" since 2000. Consistent with this, Bessen (2016) also argues that political influence, in the form of lobbying and campaign contributions, and regulations are important factors in explaining rising corporate profits, 
especially since 2000 .

\section{Large Firms, Patenting, and Creative Destruction}

Incumbent firms rely on a range of other strategies to help maintain current market positions. One of them is patenting. As one of the widely used forms of intellectual property protection, patenting was instituted to reward and promote innovation and technological advances. As a result, patents have traditionally been associated with innovation. But is this still the case? Do patents still signal technological progress, or do we witness the rise of non-productive patenting that solely serves the role of protection?

The figure 3 plots the aggregate trends in patenting and TFP growth in the U.S. In the left panel, I show the total number of patent applications in the U.S. On the right, I show a smooth 10-year trend in aggregate total factor productivity growth in the U.S. While patenting surged starting from the 80s, the TFP growth has been stalling. If patents signal innovation, why are these innovations not reflected in the aggregate statistics? It could be the case that we witness the changing nature of the innovation process, "low-hanging fruits" are grabbed, and "ideas are harder to find" (Jones, 2009; Gordon, 2016; Bloom et al., 2020). So, more patents would need to fuel the same increase in productivity. However, it could also be the case that more patents are non-productive - meant to reduce creative destruction but not to find their ways in actual innovations in the economy.

Indeed, the concerns over the strategic patenting and accumulation of patent thickets have grown over time (Cohen et al., 2000; Jaffe and Lerner, 2004; Akcigit and Ates, 2019). Nonetheless, the challenge in identifying whether patents are non-productive lies in the fact that it is hard to track innovations in the market, and patents are often our only way to proxy innovation and technological advances. Rich microdata and new ways of measuring innovation and patent content are needed to understand the nature of patenting and firms' non-productive strategies.

In a recent work in Argente et al. (2020), we attempt to do this. We focus on the empirical context of the consumer product goods (CPG) sector, where using the rich micro-level data, we can observe firms' innovations in the market and link them with firms' patents. Our data lets us disentangle productive from non-productive patents that are not associated with innovations in the marketplace. We find that patents of market leaders are often non-productive; hence they do not lead to new or better products in the market, but they are associated with reduced creative destruction in the product market. The following section will discuss the findings from this study in more detail. 
Figure 3: The U.S. Trends in Patenting And TFP growth

(a) USPTO Patent applications over time

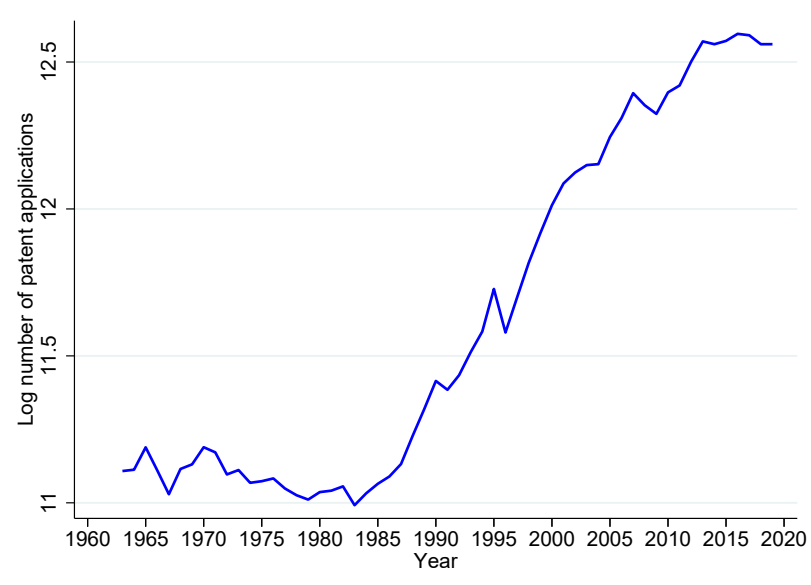

(b) TFP growth series, 10-year averages

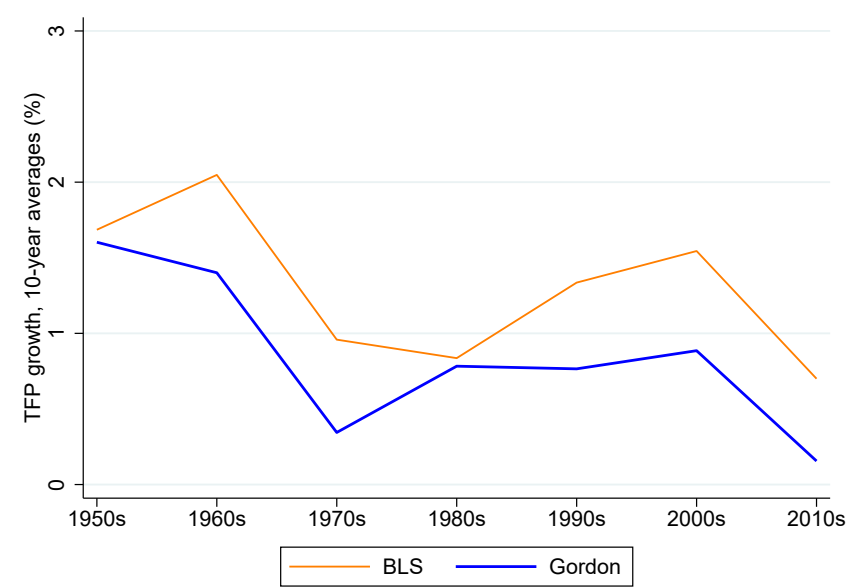

Notes: Panel (a) plots the log number of patent applications in USPTO. Source: "U.S. Patent Statistics Chart Calendar Years 1963 - 2020", USPTO. Panel (b) plots annualized 10-year TFP growth series from BLS Multifactor Productivity data and Gordon (2015). “2010s" represents the average for 2010-2014 for the Gordon series and 2010-2019 for BLS.

\subsection{Consumer Product Goods Sector}

Data and Measurement. There are two major demands on a data set that could help us identify non-productive patents. First, the data should contain information on the actual innovations - a product or process improvements in the market; and second, these innovations should be linked to patents. A simple idea then would be to identify productive patents as the ones reflected in the innovations in the market and non-productive patents as those not associated with innovations but deterring entry by competitors.

In Argente et al. (2020), we combine a rich scanner dataset on products from Nielsen Retail Measurement Services (RMS) with patent data from USPTO to meet these demands. Scanner-based datasets on products (barcodes) from grocery, drug, and generalmerchandise stores are gaining increased popularity in firm-level micro and macro studies (Hottman et al., 2016; Argente et al., 2018). The main advantage of this dataset is granular information on firms' product portfolios in the CPG sector and the nearuniversal coverage of the whole industry in the period 2006-2015. Using this information, we develop various measures of product innovation by firms.

Our measures of product innovation take into account the quantity and quality of new products introduced by firms. Using detailed product attributes and hedonic price regressions, we develop an index of novelty embedded in each new product on the 
market. Then, our preferred product innovation measure is the quality-adjusted product introduction - the number of new products weighted by their respective novelty index.

Next, we develop the matching between firms' patents and products. We study patent texts and product descriptions in our data and Wikipedia to inform us about the content of patents and products. Then, we match patents with product categories (a set of similar products) produced by firms using modern text analysis techniques. Since we cannot measure process innovation with our data, we also filter out those patents that are more likely related to the improvements in processes rather than innovations in the products.

As a result, we end up with the firm-level data with measures of firms' product innovation in various product categories and firms' patenting in those categories. Our data set covers up to 35 thousand firms in the CPG sector. These firms hold a total of one million patents, with the third of them relating to the sectors our data cover. Not surprisingly, the majority of product innovations in the data do not match to patents; hence these innovations would remain undetected with patent statistics.

Delving into microdata. With this rich data set at hand, the paper next explores patenting and innovation behavior of firms. First off, we document that firms applying for patents tend to introduce more and better products, primarily within one or two years after the patent was issued. Hence, on average, patents capture product innovation in the market.

However, we document an important heterogeneity in a patents-to-products relationship that is the key to understanding firms' use of non-productive strategies. We observe a disconnect between patenting and product innovation for firms as we move up the firm size distribution. Figure 4 is reproduced from Argente et al. (2020). Panel (a) shows the average quality-adjusted product introduction rate for firms in different firm size (sales) percentiles in product categories. As a firm's market share within a product category grows, its product innovation rate declines, with the market leader contributing proportionately least to the aggregate innovation introduced in the market.

Crucially, this decline in innovation efforts is accompanied by a disproportionate increase in patenting. Market leaders issue more patents per each new product introduced, even conditional on the size of innovation embedded in its new products: Panel (b) shows how the number of patent applications per quality-adjusted innovation increases with firm size within a narrowly defined product category. In the paper, we calculate the patents-to-innovation elasticity by firm size and find it to decline with the firm's market share in a product category. 
Figure 4: Product Innovation and Patenting over Firm Size

(a) Product innovation by firm size

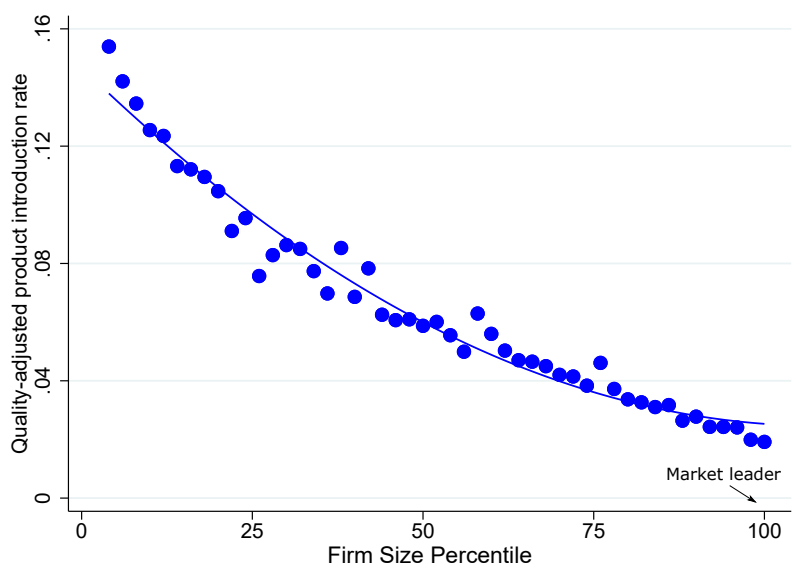

(b) Patents over product innovation by firm size

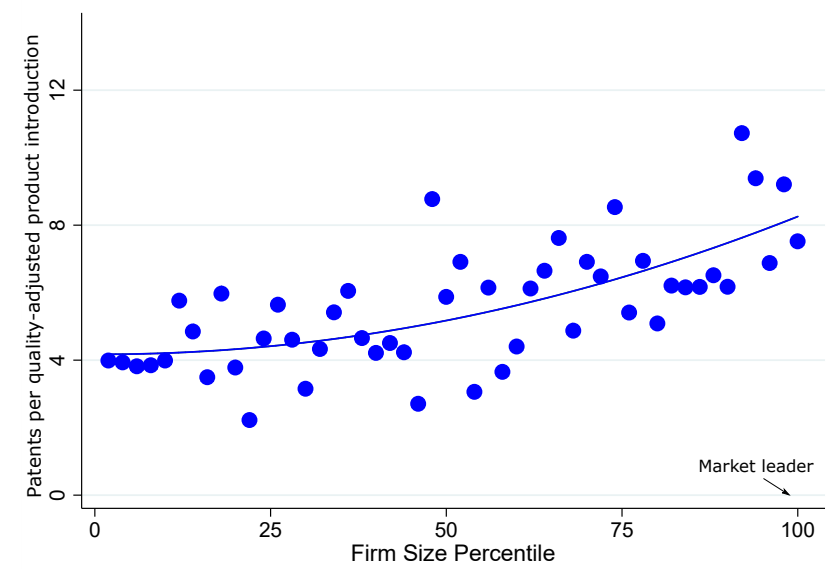

Notes: Figures are reproduced from Argente et al. (2020). Panel (a) depicts the average quality-adjusted product introduction rate for firms in different size (sales) percentiles in the product category in a year. Panel (b) depicts the ratio of patent applications over quality-adjusted new products across the firm size percentile.

By itself, this trend in the increase in patenting without accompanying product innovation would not be worrying if, instead of new products, larger firms used their patents for other productive reasons, such as process and method improvements, patent sale and licensing, or experimentation and delayed product development. Exploring our data, we do not find evidence supporting these alternative uses of patents by larger firms.

Instead, the data suggest that the increased patenting of larger firms is non-productive and limits the entry of other competitors, preserving market shares of existing incumbents. Product introduction by other firms reduces in a product category where large incumbents file more patents. The same is not true if patent filers are the smaller firms. Consistent with this, we also observe that, conditional on quantity and quality of product introduction, large firms' patents come with a bigger revenue premium; that is, market leaders monetize their patents better.

A theory of creative destruction with non-productive patenting. A small extension of the theory of growth and creative destruction provides a natural intuition for the observed facts and helps us quantify the private value of a patent. In the model where innovation and patenting decisions are different choices, we see that the link between 
innovation and patenting gets weaker for bigger firms. It is this disconnect that, through the lens of the model, identifies the extent of non-productive patenting in the data.

Our model combines two classic intuitions from the literature. Similar to the classic Arrow effect (Arrow, 1962), the model implies that market leaders benefit less from innovating and commercializing their products in the market. This effect is also at the heart of the basic Schumpeterian model of Aghion and Howitt (1992) and is prominently featured in subsequent works (e.g Akcigit and Kerr, 2018). Our model adds to this intuition by showing that market leaders, instead, rely more on non-productive strategies, such as patenting that raises barriers to creative destruction. The benefits from protection are larger for market leaders simply because they have more to lose. This intuition is similar to the preemption idea from classic work by Gilbert and Newbery (1982).

Combining these two opposite effects, the model provides a unified way to account for the reduced product innovation and increased patenting by market leaders observed in the data. The model can be used to quantitatively decompose the private value of a patent and show its implications for creative destruction in the consumer goods sector.

\subsection{Other Contexts and Policy Implications}

Argente et al. (2020) illustrates that many patents of large firms are non-productive they do not lead to actual innovations in the market and often serve as an impediment to creative destruction and reallocation. The paper focuses on the CPG sector only because of the unique opportunity presented by detailed scanner data sets. However, as highlighted by general intuition from our model, there is no reason to think that this behavior is specific only to market leaders in this sector. However, new data and new methods are needed to detect non-productive patenting in other contexts and evaluate its importance for aggregate dynamics. This section briefly overviews related micro evidence in other contexts and discusses aggregate implications and policy.

Due to data limitations, empirical evidence on whether patents transmit into actual innovations in the market is scarce. However, there is more evidence on whether patents deter the follow-on research or product introduction. Galasso and Schankerman (2014) show that when patent right is invalidated, the focal patent receives more follow-on citations from future patents. The authors look at the patent invalidation decisions by the U.S. Court of Appeal for the Federal Circuit. This setting is attractive because each patent gets assigned a panel of randomly assigned judges with different leniencies. Analyzing subsequent citation patterns of 1,258 "lucky" and "unlucky" patents, the authors find that the patent invalidation leads to about a $50 \%$ increase in the follow-on citations 
by other firms. This estimate is driven mainly by invalidated patents of large firms.

These effects are highly heterogeneous across different patent technology classes. For example, the effects are absent in the human genome field. Indeed, a study by Sampat and Williams (2019) does not find that the patent grant harms subsequent research and product development in human genes technology. In another study, Cockburn and J. MacGarvie (2011) find that entry in software products declines when there are more patents relevant to that market. Similarly, exploiting patent-publication pair data, Murray and Stern (2007) show the reduction in subsequent patent citations after a formal grant of the patent rights.

As we show in Argente et al. (2020), in addition to blocking nature, patents of market leaders are also not leading to innovations. This behavior might be partly behind a recent decline in knowledge diffusion from leaders to laggards. Akcigit and Ates (2019) (see also a chapter in this book) build an endogenous growth model incorporating various channels that could explain the salient macroeconomic changes over the last decades in the U.S. A decline in knowledge diffusion from the frontier to laggard firms is estimated to be the most significant contributor to the observed decrease in business dynamism. This channel is likely to operate in other countries, too, since Andrews et al. (2016) document the increasing gap between the frontier and laggard firms in OECD.

If the tools, originally meant to promote innovation, turn to stifle it, perhaps policy could intervene? Patent reforms are a subject of continual policy discussions (Jaffe and Lerner, 2004); and should be, given the importance of incentives that the patent policy creates. To eliminate the rise in non-productive patenting, more scrutiny, especially for the patents of large firms is needed. With the help of text analysis and machine learning tools, patent applications that are too similar to its predecessors could be singled out and their necessity and applicability could be scrutinized. In the current patent law, patented inventions are not required to be applied in practice. Perhaps, some form of Bona Fide Use from trademarks law could reduce the occurrence of non-productive patenting.

\section{Other Non-Productive Strategies}

Incumbent firms rely on various other non-productive strategies to maintain their market leadership. One of them is buying out small firms. A recent study by Cunningham et al. (2021) employs the detailed project development data in the pharmaceutical industry to convincingly show that incumbent firms use the "killer acquisition" strategy. The authors show that incumbents often buy out promising firms that could have be- 
come their rivals and subsequently discontinue the competing projects. Interestingly, all these acquisitions go under the radars of the competition authorities. According to the estimates, if these "killer" acquisitions were not allowed, the drug project development would continue for $4.3 \%$ more drugs in a year.

Cavenaile et al. (2021) build a general equilibrium growth model with innovation and M\&A activities to quantify the long-run welfare implications of antitrust policy. The authors show that strengthening the current antitrust policies would be beneficial in the long run due to higher innovation rates in a more competitive environment. In addition, the authors point out that the current HHI measures of competition used by FTC often fail to account for "anticompetitive acquisitions" since HHI measures are static, and many acquisitions target the currently small but a big-potential firms.

\section{Conclusion}

The process of creative destruction, while moving technological progress ahead, creates losers and winners along the way. It is this conflict that incentivizes the vested incumbents to find ways to resist the power of creative destruction. This chapter was devoted to reviewing recent micro-level evidence on incumbents' non-productive strategies, such as political connections, non-productive patenting, and anti-competitive acquisitions. The theory of creative destruction and growth then was used to shed light on the aggregate implications of these strategies.

Two directions for future research loom large. First, novel granular data sets and techniques are needed to identify various non-productive strategies firms use in different contexts. Uncovering these strategies then will direct our eyes towards institutional features or policies (or lack of them) that make these strategies possible. Second, to quantitatively evaluate how this micro-level evidence on non-productive strategies mounts to macro outcomes, we need to estimate rich micro-founded structural models of the macroeconomy. Of pressing importance is to evaluate how much the strategies employed by market leaders contribute to the much-discussed recent trends on the increasing market power and industry concentration, slower business dynamism, decreasing investment, and stagnating productivity growth.

\section{References}

Aghion, Philippe and Peter Howitt, "A Model of Growth through Creative Destruc- 
tion," Econometrica, 1992, 60 (2), 323-351.

Akcigit, Ufuk and Sina T. Ates, “What Happened to U.S. Business Dynamism?," 2019. National Bureau of Economic Research Working Paper 25756.

_ and _ , "Ten Facts on Declining Business Dynamism and Lessons from Endogenous Growth Theory," American Economic Journal: Macroeconomics, January 2021, 13 (1), 257-298.

- and William R. Kerr, "Growth through Heterogeneous Innovations," Journal of Political Economy, 2018, 126 (4), 1374-1443.

_, Salomé Baslandze, and Francesca Lotti, "Connecting to Power: Political Connections, Innovation, and Firm Dynamics," NBER Working Papers 25136, National Bureau of Economic Research, Inc October 2018.

Andrews, Dan, Chiara Criscuolo, and Peter N. Gal, "The Best versus the Rest: The Global Productivity Slowdown, Divergence across Firms and the Role of Public Policy," OECD Productivity Working Papers, No. 5, OECD Publishing, Paris, 2016, (5).

Argente, David, Munseob Lee, and Sara Moreira, "How do Firms Grow? The Life Cycle of Products Matters," 2018 Meeting Papers 1174, Society for Economic Dynamics 2018.

_ , Salomé Baslandze, Douglas Hanley, and Sara Moreira, "Patents to Products: Product Innovation and Firm Dynamics," CEPR Discussion Papers 14692, C.E.P.R. Discussion Papers May 2020.

Arrow, Kenneth, "Economic Welfare and the Allocation of Resources for Invention," in "The Rate and Direction of Inventive Activity: Economic and Social Factors" NBER Chapters, National Bureau of Economic Research, Inc, December 1962, pp. 609-626.

Autor, David, David Dorn, Lawrence F Katz, Christina Patterson, and John Van Reenen, "The fall of the labor share and the rise of superstar firms," The Quarterly Journal of Economics, 2020, 135 (2), 645-709.

Baumol, William J., "Entrepreneurship: Productive, Unproductive, and Destructive," Journal of Political Economy, 1990, 98 (5, Part 1), 893-921.

Bessen, James E, "Accounting for Rising Corporate Profits: Intangibles or Regulatory Rents??," 2016. Boston Univ. School of Law, Law and Economics Research Paper No. 16-18. 
Bloom, Nicholas, Charles I. Jones, John Van Reenen, and Michael Webb, "Are Ideas Getting Harder to Find?"' American Economic Review, April 2020, 110 (4), 1104-44.

Bombardini, Matilde, Olimpia Cutinelli Rendina, and Francesco Trebbi, "Lobbying Behind the Frontier," Working Paper 29120, National Bureau of Economic Research August 2021.

Cavenaile, Laurent, Murat Alp Celik, and Xu Tian, "The Dynamic Effects of Antitrust Policy on Growth and Welfare," Journal of Monetary Economics, 2021, 121, 42-59.

Cockburn, Iain and Megan J. MacGarvie, "Entry and Patenting in the Software Industry," Management Science, 05 2011, 57, 915-933.

Cohen, Wesley M, Richard R Nelson, and John P Walsh, "Protecting Their Intellectual Assets: Appropriability Conditions and Why U.S. Manufacturing Firms Patent (or Not)," Working Paper 7552, National Bureau of Economic Research February 2000.

Comin, Diego and Bart Hobijn, "Lobbies and Technology Diffusion," The Review of Economics and Statistics, May 2009, 91 (2), 229-244.

Cunningham, Colleen, Florian Ederer, and Song Ma, "Killer acquisitions," Journal of Political Economy, 2021, 129 (3), 000-000.

Decker, Ryan, John Haltiwanger, Ron Jarmin, and Javier Miranda, "Where has all the skewness gone? The decline in high-growth (young) firms in the U.S," European Economic Review, 2016, 86 (C), 4-23.

Galasso, Alberto and Mark Schankerman, "Patents and Cumulative Innovation: Causal Evidence from the Courts," The Quarterly Journal of Economics, 11 2014, 130 (1), 317-369.

Garicano, Luis, Claire Lelarge, and John Van Reenen, "Firm Size Distortions and the Productivity Distribution: Evidence from France," American Economic Review, November 2016, 106 (11), 3439-79.

Gilbert, Richard and David Newbery, "Preemptive Patenting and the Persistence of Monopoly Power," American Economic Review, 02 1982, 72, 514-26.

Glode, Vincent and Guillermo Ordoñez, "Technological Progress and Rent Seeking," 2021. Working paper. 
Gordon, Robert J., "Secular Stagnation: A Supply-Side View," American Economic Review, May 2015, 105 (5), 54-59.

_ , The Rise and Fall of American Growth: The U.S. Standard of Living since the Civil War, 1 ed., Princeton University Press, 2016.

Gratton, Gabriele, Luigi Guiso, Claudio Michelacci, and Massimo Morelli, "From Weber to Kafka: Political Instability and the Overproduction of Laws," American Economic Review, September 2021, 111 (9), 2964-3003.

Gutiérrez, Germán and Thomas Philippon, "Declining Competition and Investment in the U.S.," Working Paper 23583, National Bureau of Economic Research July 2017.

_ and _ , "The failure of free entry," Technical Report, National Bureau of Economic Research 2019.

Hottman, Colin J., Stephen J. Redding, and David E. Weinstein, "Quantifying the Sources of Firm Heterogeneity," The Quarterly Journal of Economics, 03 2016, 131 (3), 1291-1364.

Hsieh, Chang-Tai and Peter J Klenow, "Misallocation and Manufacturing TFP in China and India," The Quarterly Journal of Economics, 2009, 124 (4), 1403-1448.

Jaffe, Adam and Josh Lerner, "Innovation and Its Discontents: How Our Broken Patent System is Endangering Innovation and Progress, and What to Do About It.," Princeton University Press, Princeton, NJ, 2004.

Jones, Benjamin F., "The Burden of Knowledge and the "Death of the Renaissance Man": Is Innovation Getting Harder?," The Review of Economic Studies, 01 2009, 76 (1), 283-317.

Krusell, Per and Jose-Victor Rios-Rull, "Vested Interests in a Positive Theory of Stagnation and Growth," Review of Economic Studies, 1996, 63 (2), 301-329.

Loecker, Jan De, Jan Eeckhout, and Gabriel Unger, "The rise of market power and the macroeconomic implications," The Quarterly Journal of Economics, 2020, 135 (2), 561-644.

Mukoyama, Toshihiko and Latchezar Popov, "The Political Economy of Entry Barriers," Review of Economic Dynamics, 2014, 17 (3), 383-416. 
Murphy, Kevin M., Andrei Shleifer, and Robert W. Vishny, "The Allocation of Talent: Implications for Growth," Quarterly Journal of Economics, 1991, 106 (2), 503-530.

Murray, Fiona and Scott Stern, "Do formal intellectual property rights hinder the free flow of scientific knowledge?: An empirical test of the anti-commons hypothesis," Journal of Economic Behavior \& Organization, 2007, 63 (4), 648-687. Academic Science and Entrepreneurship: Dual engines of growth.

Restuccia, Diego and Richard Rogerson, "Policy Distortions and Aggregate Productivity with Heterogeneous Establishments," Review of Economic Dynamics, 2008, 11 (4), $707-720$.

Sampat, Bhaven and Heidi L. Williams, "How Do Patents Affect Follow-On Innovation? Evidence from the Human Genome," American Economic Review, 2019, 109 (1), 203-36.

Schumpeter, Joseph A., “Capitalism, Socialism and Democracy,” 1942. 